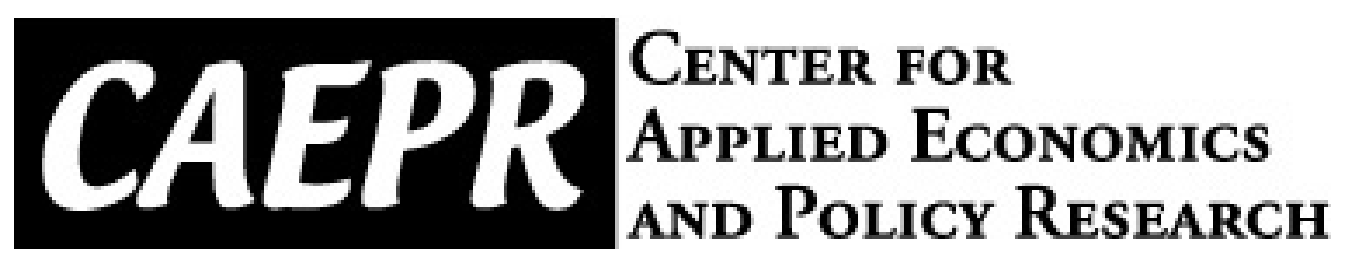

CAEPR Working Paper

\#022-2009

\title{
Reevaluating the Effect of Non-Teaching Wages on Teacher Attrition
}

\section{Gregory Gilpin}

\section{Montana State University \\ November 2009}

This paper can be downloaded without charge from the Social Science Research Network electronic library at: http://ssrn.com/abstract=1505390.

The Center for Applied Economics and Policy Research resides in the Department of Economics at Indiana University Bloomington. CAEPR can be found on the Internet at: http://www.indiana.edu/ caepr. CAEPR can be reached via email at caepr@indiana.edu or via phone at 812-855-4050.

(C2008 by NAME. All rights reserved. Short sections of text, not to exceed two paragraphs, may be quoted without explicit permission provided that full credit, including $₫$ notice, is given to the source. 


\title{
Reevaluating the Effect of Non-Teaching Wages on Teacher Attrition
}

\author{
Gregory Gilpin ${ }^{\mathrm{a}}$
}

November 2009

\begin{abstract}
Most researchers find that the non-teaching wage has a significant effect on teacher attrition. Surprisingly no study that estimates this effect actually uses former teachers' wages. The use of aggregate wage data can potentially cause upward bias coefficients due to selection issues. Using wages of former teachers in a simultaneous probit-tobit system of equations, the effect is estimated and found to be insignificant. The results indicate that higher teaching wages and student teaching significantly lower attrition while being attacked or threatened during the previous school year and whether the teacher lives in a household with income above $\$ 40,000$ significantly increase attrition.
\end{abstract}

JEL classification: H52, I22, J44, J31

Keywords: teacher attrition, non-teaching wage, teacher practicum

${ }^{a}$ Department of Agricultural Economics and Economics, Montana State University, Bozeman, MT, 59718, USA. Phone: (406) 994-5628, gregory.gilpin@montana.edu 


\section{Introduction}

The attrition rate of teachers continues to receive significant attention both by researchers and by policymakers. One of the main questions is whether teacher attrition is driven by the allure of higher paying jobs in alternative occupations. Surprisingly, no study that estimates the effect of non-teaching wages or the wage premium (the difference in non-teaching to teaching wages) on teacher attrition uses former teachers' non-teaching wages. The majority of papers use aggregated data such as average starting wage based on the teachers' degree subjects (Murnane et al (1989)), county-level per-capita earnings (Imazeki (2005), Ondrich et al (2008)), relative income of college graduates who are not teachers (Flyer and Rosen (1997), Ballou and Podgursky (1997), Loeb and Page (2000)), or regional dummy variables (Hanushek et al. (2004)). All of these papers find that teachers are more likely to leave the teaching profession due to higher non-teaching wages or the wage premium.

The reliance on constructed non-teaching wages is due to the limited availability of former teacher data. The majority of data on teachers are from administrative records, which do not track teachers after they depart from teaching. One known paper that has such data is Scafidi et al. (2006), who map public data from Georgia school administrative records to Georgia Department of Labor data to investigate whether teachers who leave the teaching profession earn higher salaries at their outside jobs. Their descriptive analysis finds that very few of those who leave teaching take jobs that pay more than the minimum teacher salary. However, no regressional analysis is performed.

Given that Scafidi et al. (2006) find few former teachers earn higher wages upon exiting teaching in Georgia, this brings into question why studies find positive significant non-teaching wage effects on teacher attrition. While not formally proven in this paper, it is highly probable 
that the imputed non-teaching wages, based on an aggregate of similar non-teaching individuals' wages (e.g., the mean or median income/earnings of similar individuals), are too large and overstate how much a teacher may earn outside of teaching. There are some compelling reasons why this might be the case. Given that most distributions of wages are right-skewed, imputed non-teaching wages based on the mean of individuals similar to the teacher overstates the wage the teacher would most likely earn. Taking the mean of the groups' log wages or the median of the groups' wages seems more appropriate but may also be problematic. If differences exist in the wages that former teachers can garner in non-teaching jobs, then these constructed medians represent the mean or median non-teaching wages of the pool of non-teachers and not that of teachers, i.e., selection issues matter. For example, education degrees are highly specialized and these skills may not be as valuable in the non-teaching sector as non-education degrees, as such, the median wage of the teachers' university classmates may overstate the teachers' potential nonteaching wage. Thus, any statistically significance of imputed non-teaching wages on teacher attrition may be due to the data construction process.

The biggest hindrance to direct estimation of the effect of the non-teaching wage or wage premium on teacher attrition is that only one of the two wages is observable based on the teachers' decisions to exit the teaching profession. This means that estimating the effect of the non-teaching wage or wage premium necessarily requires the estimation of some wages. Given that relying on aggregate non-teachers' wages may generate a statistically significant effect when in actuality there may or may not be one, a more precise wage estimation technique is required, one which takes into consideration selection issues.

The purpose of this paper is two-fold. The first is to estimate non-teaching wages of teachers who remain in teaching. The restricted-access Teacher Follow-up Survey (TFS) 
contains the current wages of former teachers which can be used to estimate the non-teaching wages of current teachers. Since the exit decision may be correlated with wages, selection issues still exist in estimating this wage. The second is to estimate the effect of the non-teaching wage on a teacher's decision to exit teaching. A selection model is able to estimate the wages and the effects on the teacher attrition jointly. Specifically, a simultaneous probit-tobit system of equations which estimates the exit decision along with two wage equations: one for the nonteaching wage and another for the next year's teaching wage. The system also permits the propensity to exit the teaching profession to depend on the wages which are being estimated simultaneously. By taking into consideration the self-selection of the teacher on her non-teaching wage, i.e., a teacher who can gain a higher wage outside of teaching is more likely to be observed exiting teaching, the issues of using imputed wages are absolved.

The crux of using such approach is identification. Identification can be secured through model specification or exclusion restrictions. Since the model is estimated through Maximum Likelihood Estimation (MLE), identification is secured through model identification. However, there are some natural exclusions that can be used as restrictions nonetheless. The exclusion restriction requires are regressors in the exit decision equation that are excluded from the wage equations. The potential candidates are: whether the teacher was attacked or threatened by a student during the previous school year, whether the teacher held an outside job during the school year for teaching related work and non-teaching related work, whether the teacher received a teacher practicum (student teaching), and the number of dependents under the age of five.

The descriptive statistics indicate that the wage premium is large for those who ultimately exit teaching while the estimation results indicate that the non-teaching wage is statistically 
insignificant on teacher attrition. On the other hand, those with higher teaching wages are more likely to remain teaching. The estimation also reveals that teachers who exit were attacked are threatened, and live in households with incomes above $\$ 40,000$ (excluding their own) are more likely to exit. Teacher preparedness through student teaching (teaching practicum) and state certification both reduced attrition as well. Further, classroom and student characteristics are insignificant on attrition; neither class size, number of courses, percent of limited-English students, percent of individual education plan students, percent eligible for school lunch students, or race matching between teachers and students have any effect on teacher attrition. The insignificance of classroom and student characteristics is of little surprise as these characteristics can be rectified, for the most part, by transferring schools. The only school characteristic that is statistically significant is whether the teacher works in a unionized school. Some community characteristics are also significant at lowering teacher attrition; these are: the log average earnings in the community and the unemployment rate.

The paper is organized as follows. Section 2 develops the empirical model, Section 3 provides a descriptive analysis of the data, Section 4 provides the regressional analysis of the data, and Section 5 concludes.

\section{The Exit Decision and Wage Equations Model}

Each teacher faces two wages at the end of the school year: her non-teaching wage and her next school year's teaching wage. The primary problem when trying to extract a 'causal' effect of the non-teaching wage or the wage premium on teacher attrition is that only one of two wages is observed depending on the choice of whether to remain in teaching. To address this 
issue, I use a simultaneous probit-tobit system. ${ }^{1}$ In this model, the propensity to exit the teaching profession depends on the teaching and non-teaching wages. This specification permits correlation between unobservables in the decision and wage equations and also provides an explicit role for the counterfactual or potential wages - the wages that could have been observed but is not by the econometrician due to the self-selection of teachers to either remain in teaching or to exit the profession. ${ }^{2}$

Let $w_{t, i}^{*}$ and $w_{n t, i}^{*}$ be the next year's teaching wage and non-teaching wage for individual $i$ respectively and let $\rho_{i}^{*}$ be the reservation wage premium that summarizes her specific preferences for teaching. Given these definitions, teacher $i$ is assumed to exit teaching if

$$
\ln w_{n t, i}^{*}-\ln w_{t, i}^{*}>\rho_{i}^{*}
$$

${ }^{1}$ This estimation technique was first proposed by Lee (1978) and further developed by Lee and Trost (1978) and Willis and Rosen (1979). The model is part of a class of models referred to as a Type 5 Tobit Model (Amemiya (1984)) and has been subject to considerable scrutiny over the years. See Garen (1988), Brooks et al. (1998), Chib (2007), among many others for examples of application of the model.

${ }^{2}$ The data provides a Lickert scale response on whether a school staffing action (e.g., involuntary transfer, laid-off) was important on the teacher's decision to exit the teaching profession. This indicator could potentially be used to exclude involuntary exits. However, this self-reported data have very few (less than $15 \%$ of those who exit) indicating so. Another issue is that no additional information is available on whether the teacher could have simply switched to a different school. Regressional analysis conducted excluding these individuals found no change in the magnitude of coefficients or statistical significances of any of the variables. 
Since $\rho_{i}^{*}$ summarizes her preferences over teaching, this can be either positive or negative. More specifically, I assume that $\rho_{i}^{*}$ is a function of the characteristics of the teacher and the attributes of the school and community according to

$$
\rho_{i}^{*}=\alpha X_{i}+\beta A_{i}+\varepsilon_{i}
$$

where $X_{i}$ is a vector of individual characteristics, $A_{i}$ is a vector of school/community characteristics where individual $i$ taught the previous school year, and $\varepsilon_{i}$ is normally distributed with a mean of zero and a variance of $\sigma_{\varepsilon}^{2}$.

Thus teacher $i$ exits the teaching profession if

$$
\ln w_{n t, i}^{*}-\ln w_{t, i}^{*}>\alpha X_{i}+\beta A_{i}+\varepsilon_{i}
$$

Equation (3) may be written in the form of a probit model: if $d_{i}=I\left(d_{i}^{*}>0\right)=1$, then teacher $i$ chooses to exit teaching, otherwise not, according to

$$
d_{i}^{*}=\delta_{0}+\delta_{n t} \ln w_{n t, i}^{*}-\delta_{n} \ln w_{t, i}^{*}-\alpha X_{i}-\beta A_{i}-\varepsilon_{i}
$$

where $\delta_{j}$ is a scalar for $j=\{0, n t, t\}$ and the usual normalization $\sigma_{\varepsilon}^{2}=1$ is used as only the sign of $d_{i}^{*}$ is observed. The other observable variables are the limited dependent variables $w_{n t, i}$ or $w_{t, i}$ for each individual $i$. The observed wage depends on the decision to exit teaching, i.e.,

$$
\begin{aligned}
& w_{n t, i}=\left\{\begin{array}{cc}
w_{n t, i}^{*} & \text { if } d_{i}^{*}>0 \\
- & \text { if } d_{i}^{*} \leq 0
\end{array}\right. \\
& w_{t, i}=\left\{\begin{array}{cc}
w_{t, i}^{*} & \text { if } d_{i}^{*} \leq 0 \\
- & \text { if } d_{i}^{*}>0
\end{array}\right.
\end{aligned}
$$

The interest of the model is to correctly estimate $\partial E\left[d^{*}\right] / \partial \ln w_{n t, i}^{*}$. This shows how the expected probability of leaving the teaching profession changes with the non-teaching wage. 
The approach of this paper is to create the counterfactual wages by making strong distributional assumptions. There are two wage equations per teacher: one equation for her nonteaching wage and another equation for her teaching wage. These are

$$
\begin{aligned}
& \ln w_{t, i}^{*}=\theta_{t 0}+\theta_{t 1} Y_{i}+\theta_{t 2} B_{i}+u_{t, i} \\
& \ln w_{n t, i}^{*}=\theta_{n t 0}+\theta_{n t 1} Z_{i}+u_{n t, i}
\end{aligned}
$$

where $\theta_{0 j}$, and $u_{j, i}$ are scalars for $j=\{n t, t\}$, and $Z_{i}, Y_{i}, B_{i}, \theta_{n t 1}, \theta_{t 1}, \theta_{t 2}$ are matrices; there are $N$ observations, i.e., $i=1, \ldots, N . Z_{i}$ are personal characteristics and experience related to the non-teaching workforce, $Y_{i}$ are personal characteristics and experience related to teaching while $B_{i}$ are school characteristics along with wage structure characteristics of the school where the teacher taught the previous year. ${ }^{3}$ In this model, the wage equations (6) and (7) cannot be consistently estimated by OLS using the observed wage since $E\left(u^{n t} \mid d=1\right) \neq 0$ and $E\left(u^{t} \mid d=0\right) \neq 0$.

A simple way of obtaining consistent estimations of the exit decision is to substitute the wage equations (6) and (7) into (4) yielding the reduced form for $d_{i}^{*}$ :

$$
d_{i}^{*}=\gamma_{0}+\gamma_{1} Y_{i}+\gamma_{1} B_{i}-\gamma_{1} Z_{i}-\alpha X_{i}-\beta A_{i}+\varepsilon_{i}^{*}
$$

where $\varepsilon_{i}^{*}=\varepsilon_{i}+u_{t, i}+u_{n t, i}$. The estimates are consistent but the effects of the direct effect of the teaching and non-teaching wage are no longer available in this reduced form. These can be backed out once consistent estimates of the wages are obtained. To do this requires additional structure. A common approach is to permit the errors to be joint normal:

\footnotetext{
${ }^{3}$ District characteristics are used for public schools since the SASS provides this information at a district level.
} 


$$
\left[\begin{array}{c}
\varepsilon^{*} \\
\eta_{t} \\
\eta_{n t}
\end{array}\right] \sim N\left[\left[\begin{array}{l}
0 \\
0 \\
0
\end{array}\right],\left[\begin{array}{ccc}
1 & \sigma_{d t} & \sigma_{d n t} \\
\sigma_{d t} & \sigma_{t}^{2} & \sigma_{t n t} \\
\sigma_{d n t} & \sigma_{t n t} & \sigma_{n t}^{2}
\end{array}\right]\right]
$$

The system of equations (6)-(9) is now the same as a Roy model. There are multiple ways to estimate this system. The generic estimation procedure consists of three steps. The first step is to estimate the reduced form model to obtain consistent estimates of the $\hat{\theta}$ s. The most common approach to obtain consistent estimates is Heckman's two-step method (see Heckman 1979). While Heckman's two-step method is widely used, it is not efficient. Maximum likelihood estimation (MLE) is consistent and efficient but sometimes has difficulty converging. The loglikelihood function, $l_{i}$, for teacher $i$ for this system of equations is given by ${ }^{4}$

$$
l_{i}=\left\{\int_{0}^{\infty} f\left(d_{i}^{*}, w_{t, i}\right) d d_{i}^{*}\right\}^{d_{i}}\left\{\int_{-\infty}^{0} f\left(d_{i}^{*}, w_{n t, i}\right) d d_{i}^{*}\right\}^{1-d_{i}}
$$

where $f\left(w_{t, i} \mid d_{i}^{*} \leq 0\right)$ is the bivariate normal density of $w_{t, i}$ and $d_{i}^{*}$, and $f\left(w_{n t, i} \mid d_{i}^{*} \leq 0\right)$ is the bivariate normal density of $w_{n t, i}$ and $d_{i}^{*}$. Since $\sigma_{t n t}$ does not enter the likelihood, estimation on the exit decision and each wage equation can be done separately (See Cameron and Trevidi (2005)). Step 1 is estimated by MLE unless it does not converge and then Heckman's two-step method is applied. Step 2 consists of constructing the estimated wages $\ln \hat{w}_{n t, i}^{*}$ and $\ln \hat{w}_{n t, i}^{*}$ using the $\hat{\theta}$ s from step 1 . The last step consists of treating the wage instruments as fixed regressors and replace $\ln w_{n t, i}^{*}$ and $\ln w_{n t, i}^{*}$ in the right-hand side of (4) with $\ln \hat{w}_{n t, i}^{*}$ and $\ln \hat{w}_{n t, i}^{*}$. The structural parameters are then estimated by Probit MLE. Estimates of the structural parameters are consistent and asymptotically normal.

\footnotetext{
${ }^{4}$ See Amemiya (1984) for further details.
} 
Selection models require identification through either model specification or through exclusion restrictions. For both estimation procedures, identification can be obtained theoretically through model specification. However, there are some natural regressors that are available to use as exclusion restrictions. The first two are whether an additional job was held during the school year for both teaching related work and non-teaching related work. Both of these are labor supply indicators. Whether a teacher was attacked or threatened by a student during the previous school year should also affect a teachers' decision to exit teaching. Student teaching or a teacher practicum should affect a teachers' decision to exit teaching as these individuals are more informed of what teaching entails, providing an opportunity to try out teaching prior to entering the teacher labor force. ${ }^{5}$ Last is the number of dependents under the age of five. Teaching is location specific and the teaching schedule is quite inflexible. Individuals may find other occupations more flexible which better suit them when they have young children.

Statistical analysis indicates that these variables are strong instruments to identify the teachers' decision to exit teaching. A non-teaching outside job, being attacked or threatened, receiving a teacher practicum, and number of children under 5 are all positive and significantly correlated with the decision to exit teaching, while outside jobs related to teaching is negatively correlated, but not significantly. All of the variables are statistically insignificant in both wage equations (along with the correlations between the exclusion variables and the wages) and are all

\footnotetext{
${ }^{5}$ The data indicates that only $54 \%$ of those who have taken a practicum are also state certified. A practicum should be excluded from the teaching wage equation as this may increase first year wages and is hence already built-in; thus, further increases from the practicum are not expected in the second year.
} 
statistically significant in the exit decision equation. Testing exclusion restrictions are performed using separate F-tests with hypotheses that the identification variables have coefficients equal to zero in the exit and wage equations. The alternatives are that at least one of the coefficients is different from zero for each equation. The tests failed to reject the hypotheses for both wage equations (p-values of .59 and .19 for the teaching and non-teaching wages) while rejecting the hypothesis for the decision equation (p-value of .0061). Thus, there is theoretical and statistical evidence that these instruments are strong and valid.

\section{Data and Descriptive Analysis}

The data comes from a sample of first year teachers from the restricted-access version of the Teacher Follow-up Survey (TFS) for school years 2000-01 and 2004-05 along with school data contained in the Schools and Staffing Survey (SASS) for school years 1999-2000 and 20032004. ${ }^{6}$ The TFS is comprised of a subsample of teachers from the SASS. ${ }^{7}$ These datasets provide information on current and former teachers and their schools. Specifically, for each former teacher, the data includes the occupational status and sector, current wage, and socioeconomic characteristics that permit an evaluation of the teacher-specific covariates along with the non-

\footnotetext{
${ }^{6}$ Information regarding the sampling technique and survey layout is provided on the National Center for Education Statistics website 'Schools and Staffing Survey'. See the References section of this paper for further information.

${ }^{7}$ The two rounds of data do not link the teachers over time, creating a stock sample. The main feature of stock sampling is spell length bias as the probability of being in the sample increases with spell length (see Lancaster, 1990). The complexities of stock sampling are eliminated since the stock is also a flow for first year teachers.
} 
teaching wage. The data contains information on teachers in public, public charter, parochial and non-parochial private schools. It also contains a wide variety of school policies where the teachers taught. Unlike district or state level data, the TFS tracks teachers when they move out of district or state bounds. Thus, current and former teachers are accounted for regardless of where they relocate.

The full construction of the data is left to an appendix (available from the author upon request). The teacher data from TFS is merged with school characteristics and additional teacher variables from the SASS files by teacher and school/district control numbers. One drawback of the TFS data is that it does not contain any measure of ability and scholastic aptitude. The SASS does contain the university that teachers attended for their undergraduate degree. Using data from the National Postsecondary Aid Study, the average ACT score for each university is calculated and matched to each teacher. To obtain economic indicators around the school locale, census data is merged by 3-digit zip code to the school where the teacher taught the previous year. The 3-digit zip code aggregate is chosen to encompass most of a teacher's local job search area. The final sample consists of 1,118 current and former teachers who have just completed their first year teaching.

The main interest is to estimate the effects of the non-teaching wage and various covariates on first year teachers' decision to exit the teaching profession. Descriptions and summary statistics of these variables are reported in Table 1. The exit decision variables in equation (4) include teacher characteristics (female, married, non-white, under the age of 27, household with over $\$ 40 \mathrm{~K}$ income, number of children under the age of five, ACT score, outside teaching job, outside non-teaching job, dummies for type of degree the teacher holds (special ed. degree, math or science degree, advanced degree), teacher preparedness variables (state 
certification, teacher practicum, ed. degree), classroom characteristics (class size, number of courses, attacked or threatened), school characteristics (union, public), and local economic indicators (percent with $\mathrm{BA}+$, community log earnings, unemployment rate, urban).

The variables of the $\log$ of teaching wage estimation, equation (6), include the log of last years' teaching wage ( $\log ($ school wages)), dummies for type of degree the teacher holds (special ed. degree, math or science degree, ed. degree, advanced degree), teacher preparedness variable (state certification), and demographic characteristics (gender, race, married). Since most public schools have a salary schedule regardless of unionization, an interaction term adv_degXpublic between a teacher working in a public school and having an advanced degree is required. The variables of the log of non-teaching wage estimation, equation (7), include the log of last year's teaching wage (log(school wages)), degree type and level (math or science degree, advanced degree, ed. degree), work experience (experience, squared experience), demographic characteristics (female, non-white, married, ACT score, household with above $\$ 40 \mathrm{~K}$ income), and local labor market indicators (percent with BA+, community log(earnings), unemployment rate, urban, year 2000). Last year's teaching wage is included as this is a part of their earnings profile and provides individuals exiting teaching with a reference point when bargaining for wages outside of teaching.

The mobility rates of the teachers are provided in Table 2 . Approximately $75 \%$ of all teachers remained teaching at the same school as the previous year, $15 \%$ remained teaching fulltime but at a different school, while $11 \%$ exited the teaching profession. Teachers who remain at the same school or teach at a different school are grouped together as 'Stayers'. 'Exiters' are those who are no longer full-time teachers. 
The current and expected occupational status of former teachers is provided in Table 3. The majority of former teachers, $64 \%$ of them, exited full-time teaching to start a new occupation. The remaining third either exited the workforce or are currently unemployed. This data is in stark contrast to data using the NLS-72 used by Stinebrickner (2002) in which 67.5\% of those who exited teaching exited the labor force as well. Since the TFS survey is administered early in the school year, the high unemployment rate is most likely picking up the transitional unemployment from leaving full-time teaching and not yet obtaining employment elsewhere. This is somewhat validated by responses of former teachers on what they expect their occupational status to be the following school year $(.1 \%$ indicated that they would be unemployed and seeking work); however, no secondary follow-up is conducted to verify their expectations. ${ }^{8}$ It is interesting that many individuals continue to work inside the field of education but in non-teaching positions. On the other hand, those who left the education sector have no plan to return. In fact, the data indicates that an additional $6 \%$ expect to obtain positions outside of education in the following year.

Table 4 provides the average earnings of current and former teachers in their first year of teaching (previous year) and the average earnings in their current occupation. Since individuals unemployed or not in the labor force do not have a wage, they are excluded for the current year's wage only. Comparing current to former teachers' wages as teachers during their first year, the

\footnotetext{
${ }^{8}$ The model could be generalized to include the decision to exit the labor force (See Lee (1983), Dubin and McFadden (1984), and Dahl (2002) for model specifications). Given limited data on those who exit the labor force, it is not feasible to model separate decisions. Regressions excluding these individuals provided similar estimates. The omitted non-teaching wages of these individuals is a non-issue as they can be estimated along with current teachers.
} 
data indicate that those who remained in teaching earned $\$ 3,416$ more than those who left. Current wages of former teachers in their new occupation are much closer to those who remain in teaching, a difference of $\$ 404$. For those teachers who remain teaching, their wages grew by $\$ 1,267$ while wages of those who exited grew by $\$ 4,280$.

\section{Results}

\subsection{Estimates of the Wage Equations}

Table 5 presents the estimates on the covariates in the wage equations. These coefficients measure the effect that increasing a particular variable has on real yearly log wages. The coefficients on most variables have the expected signs and significance. Last year's teaching wage and the indicator for female had predictive power on next year's salary, however, none of the other coefficients are close in magnitude to previous year's wage ${ }^{9}$. This is not a surprise since most institutional differences are already built into the previous year's teaching wage.

The statistically significant coefficients of the non-teaching wage equation are last year's wage, the indicator that the teacher lived in a household earning over $\$ 40,000$ (excluding her/his own wage), and the percent in the community with a bachelor's degree or beyond. Separate Wald tests are conducted to test whether the teaching and exit decision equations and the nonteaching wage and exit decision equations are independent. The hypothesis is rejected at a $1 \%$

\footnotetext{
${ }^{9}$ The TFS contains information on whether schools can provide incentive based pay. Preliminary regression indicated that incentives have insignificant effects on raising teachers' wages. This may reflect that incentives are built into their previous year's wage or that retaining first year teachers may not be as high of a priority as experienced teachers. Since data is only available for one round, this variable has been excluded to increase sample size.
} 
level for the teaching wage and at a 5\% level for the non-teaching wage. The MLE estimation process also provides the statistics $\rho$ and $\lambda . \rho$ indicates the correlation between the exit equation and the teaching and non-teaching wages respectively. Both correlations are strong and significant. $\lambda$ is the control function in the wage equation or the inverse Mill's ratio. This can be considered the omitted variable which, when included, unbias the coefficients in the wage equations. If the control function is statistically significant, then selection issues are important and the control function has adjusted the other coefficients for selection. Both $\lambda$ are statistically significant. Thus, these statistics indicate that sample selection correction is needed.

\subsection{Estimates of the Exit Decision Equation}

The marginal effects and their standard errors obtained from maximum likelihood probit of the structural exit decision equation are reported in Table 6. The marginal effects are calculated at the means of the continuous independent variables (see Table 1) and uses discrete changes of 0 to 1 for dummy variables. The coefficients estimates are precisely determined in general and most have the expected signs and significances. The pseudo R-squared is .22.

\subsubsection{Wages}

One of the main purposes of this paper is to investigate whether, and to what extent, the non-teaching wage affects the decision to exit the teaching profession. The coefficient on the non-teaching wage is highly insignificant. On the other hand, teachers' wages is highly significant and has a negative effect on teacher attrition. One way to check the robustness of the wage effects is by adjusting the wage instruments (with all other variables remaining the same). This is done by replacing all non-teaching and teaching wages with the estimated wages 
provided by step 2 as outlined in Section 2, and not just censored wages. The results do not change with this robustness check, the non-teaching wage coefficient remains insignificant while the teaching wage coefficient remains significant.

\subsubsection{Teacher-specific Characteristics}

The data provided in the TFS survey permits a very extensive examination of the relationship between teacher characteristics and the decision to exit teaching. As expected, gender, race, age, and marital status are not significant effect on teacher attrition. Similar to Stinebrickner (2002), each additional dependent under the age of five has a significant effect on a teachers' decision to exit teaching. ${ }^{10}$ Teachers who live in households with incomes above $\$ 40 \mathrm{~K}$ (excluding their own wage) are $40 \%$ more likely to exit teaching. This may indicate that these individuals' labor wages are not the primary income source for their household, permitting these individuals to be choosier in job selection. ${ }^{11}$ Another branch of literature has indicated that higher ability individuals are less likely to remain in teaching (see Murnane and Olsen 1989). The results indicate that those with higher ACT score are not any more likely to leave than those of lower scores. Considering this measure is computed based on the teacher's university average, little can be interpreted by this result and should not be taken as evidence against the existing results from the literature.

${ }^{10}$ Stinebrickner (2002) uses data on whether a child was born. The TFS does not provide such information.

${ }^{11}$ Due to the wording of the TFS survey questions, all additional sources are included in the total household income including a spouse and any secondary income from outside jobs and non-labor income sources. 
The signs for the effect of degree level or type are as expected: the effect is positive for individuals with a math or science degree, negative for individuals with advanced degrees, and negative for individuals with special education degrees. However, none of these variables are significant accept holding an education degree. Even though the estimation conditions on wages should mute these effects, there is an additional non-wage reason why degree type and level may make a difference on the exit decision: individuals may earn advanced degrees to become certified and are more committed to the profession.

\subsubsection{Teacher Preparedness}

There are three indicators for teacher preparation available in the TFS: whether the teacher is state certified, whether a teacher had a practicum prior to beginning full-time teaching, and degree type. State certification reduces a teachers' probability to exit teaching by 5.7 percentage points (statistically significant at 5\%) while having a practicum generates a 12 percentage points decrease in the probability to exit teaching (statistically significant at $1 \%$ ). The effect of holding an education degree is the smallest with a decrease of $5 \%$. Since only half of all teachers who are state certified receive a practicum, being state certification does not imply that the teacher had any classroom experience prior to commencing teaching. These results are also consistent with Goldhaber and Brewer (2000) and Wilson and Ferrini-Mundy (2001, 2002).

\subsubsection{Classroom and School Characteristics}

The classroom and school characteristics are grouped together as they both affect the work environment of teachers. Being attacked or threatened during the previous school year increases the probability of exiting by 13 percentage points. This is new in the literature and is a 
serious concern. All of the remaining classroom and school characteristics' effect are insignificant except whether the school where the teacher taught the previous year was unionized. The effect of unionization generates a 10 percentage point decrease in the probability of exiting teaching. This may indicate that unions provide barriers to dismissal which prevent teachers from being dismissed or that unions provide better working environments which teachers find more favorable.

\subsubsection{Community Characteristics}

The economic environment of the community in which the school is located also affects a teacher's decision to exit teaching. In an effort to encompass a large portion of teachers' local employment search area, the community data is aggregated to the 3-digit zip code level. The results indicate that as the local unemployment rate rises, teachers are less likely to leave the teaching profession. Another significant effect is the average earnings in the community. As community earnings increase, teachers in those communities are less likely to leave teaching. This may be due to the fact that higher income communities tend to have more parental engagement in the classroom or that there are fewer issues at schools with children from these communities.

\subsection{Robustness of Results}

Robustness checks are conducted to verify the results. There are three additional specifications that seem appropriate: subsampling the data by gender, including additional student and school characteristics, and a parsimonious model excluding many insignificant and low power variables. Gender subsampling is done as female labor supply decisions have 
traditionally been different than males. For instances, females tend to be the primary caregiver of young child and are more likely to take leave after a baby is born. It also provides a benchmark to other estimations of female exit decision research (see Stinebrickner (2002), Imazeki (2005), Ondrich et al. (2008)). Student and school characteristics are more likely to affect the decision to switch schools and hence to remain in teaching. Both Hanushek et al. (2004) and Imazeki (2005) found significant effects of student and school characteristics on a teachers' decision to exit teaching. The student characteristics are the percent eligible for free lunch, the percent of nonwhite, interaction of non-white teachers with percent of non-white students, the percent of limited-English proficiency students, and the percent of individual education plan students. However, the plausibility of a teacher exiting teaching instead of switching schools due to one of these characteristics is quite low.

For brevity, I provide the marginal effects for the structural exit decision equations for a select number of variables for females and males in Table 7. The estimates indicate that many of the prior results still hold. The effect of the non-teaching wage remains insignificant for both genders while the effect of the teaching wage is significant and almost double for male teachers as female teachers. The effect of teacher preparedness remains the same with male teachers more likely to stay if they have had a teacher practicum. The effect of state certification is a 5 percentage point decease in the probability to exit teaching for females compared to a 12 percentage point difference for males. Interestingly, the effect of living in households with incomes above $\$ 40 \mathrm{~K}$ is almost twice as large for males as females which increases the probability of exiting by 57 percentage points.

Table 8 provides the marginal effects for the extended and reduced specifications with the baseline marginal effects included for reference. In either specification, the effect of the non- 
teaching wage remains statistically insignificant while the effect of the teaching wage remains positive and significant on teacher attrition. In the extended specification, classroom and school characteristics are included. Of the classroom characteristics, the number of distinct courses taught in a given week (which identifies the number of preparations) and class size, both have insignificant effects on a teachers' decision to exit teaching. Further, all of the school characteristic coefficients have insignificant effects as well. There are a few effects which are no longer significant in the extended specification. These effects are state certification and the number of dependents under the age of five.

In the reduced specification, many of the teacher-specific characteristics are excluded because they had no estimated effect in the baseline specification or in the literature. The results indicate that the effects all remain statistically significant from the baseline specification with only a few effects changing in magnitude. The magnitude of effect of a practicum increases by .2 percentage points, the magnitude of effect of being threaten or attacked decreases by 1.3 percentage points, the magnitude of effect of unions increases by 2 percentage points, and the magnitude of effect of community earnings decreased by .79 percentage points.

\section{Conclusions and Policy Implications}

In this paper the effect of the non-teaching wage on teacher attrition is examined. The results indicate that the effect of the non-teaching wage is statistically insignificant. In an attempt to provide some assurance to this result, multiple regressions with various specifications are performed. None of the results of the various specifications change the statistical insignificance or low magnitude of the effect of non-teaching wages on teacher attrition. The descriptive statistics indicate that those who are observed exiting the teaching profession earn more than as 
teachers. However, their outside wage is quite equivalent to that of teachers who remain in the teaching profession. This is due to former teachers' teaching wages being considerably below the average of those who remain in teaching. Thus, for those who exit, working in a position outside of teaching provides similar wages to teachers who remain in teaching. The regressional analysis indicates that those who are paid more as teachers are more likely to remain. Along with wages is the effect of living in a household with incomes above $\$ 40,000$ (excluding their own). This significantly raises the probability of exiting by $40 \%$.

Some of the largest effects on teacher attrition identified in this paper are from teacher preparedness. Teachers who are better prepared through a teacher practicum are more likely to remain in teaching. This may reflect these individuals' desired to teach prior to the practicum or may also reflect that a practicum provides the first in-class experience for many individuals who think they want to become a teacher. Given no in-class experience to form expectations of what teaching entails, the teacher practicum updates these expectations with more precise information on whether they would enjoy teaching. Thus, the effect of the practicum allows individuals to opt out of teaching prior to entering the teacher labor market. Thus, a practicum can be used as a selection mechanism to prevent individuals who are most likely to exit teaching from entering the teaching profession. Allocating resources to improve teacher qualifications prior to entering the classroom may reduce teacher attrition by increasing their pay grade and by having a more committed pool of incoming teachers. ${ }^{12}$

12 On 22 October, 2009, the U.S. Education Secretary Arne Duncan speaking at Columbia University said that many institutions are doing a mediocre job of preparing teachers for the $21^{\text {st }}$ century classrooms and that teachers' college need to improve teacher preparedness through more in-class experience prior to entering the teacher labor force. 
The effects of many other variables are found to be significant on reducing attrition. As the number of children under the age of 5 increases, a teacher is more likely to exit teaching. Being attacked or threatened is also a significant effect that increases the probability of exiting by $10 \%$. This result is of serious concern which requires further evaluation by school administrators, policymakers, and researchers. Classroom characteristics have insignificant effects on teacher attrition: neither class size nor the number of courses taught affected teacher attrition. Similarly, the effects of student characteristics on teacher attrition are insignificant and of low magnitude. It seems plausible that teachers displeased with one of these characteristics can switch schools to rectify it.

All of the above results must be taken into consideration with the implicit attrition that has taken place by individuals opting out of the teaching prior to entering the teacher labor market. Changing labor market opportunities for women and unions have effectively pulled higher quality teachers out of the teaching sector prior to entering (see in Flyer and Rosen (1997), Hanushek and Rivkin (1997), Hanushek and Rivkin (2003), Goldhaber and Liu (2003), Stoddard (2003), Bacolod (2006), Lakdawalla (2006), and Gilpin and Kaganovich (2009)). Thus, any policy changes must take into consideration the effect on the pool of potential teachers. 


\section{References}

Allison, P. (1999). Comparing Logit and Probit Coefficients Across Groups. Sociological Methods Research 1999; 28; 186-208.

Amemiya, T. (1984). Tobit models: a survey. Journal of Econometrics, 24(1-2), 3-61.

Bacolod, M., 2006. Do Alternative Opportunities Matter? The Role of Female Labor Markets in the Decline of Teacher Quality, Working Paper 06-22, Center for Economic Studies, U.S. Census Bureau.

Ballou, D., and M. Podgursky. 1997. Teacher pay and teacher quality. Kalamazoo, MI: W.E. Upjohn Institute for Employment Research.

Boyd, D., H. Lankford, S. Loeb, and J. Wyckoff. (2005). The draw of home, how teachers' preferences for proximity disadvantage urban schools. Journal of Policy Analysis and Management 24 (1): 113-34.

Boyd, D, P. Grossman, H. Lankford, S Loab, and J. Wyckoff (2006). How Changes in Entry Requirements Alter the Teacher Workforce and Affect Student Achievement. Education Finance and Policy, 1(2), 176-216.

Boyd, D, P. Grossman, H. Lankford, S Loab, and J. Wyckoff (2008a). Who Leaves? Teacher Attrition and Student Achievement. NBER Working Paper 14022.

Boyd, D., H. Lankford, S. Loeb, J. Rockoff, and J. Wyckoff (2008b). The Narrowing Gap in New York City Teacher Qualifications and its Implications for Student Achievement in High-Poverty Schools. NBER Working Papers 14021.

Bureau of Economic Analysis (1): Current Dollar and Real GDP Data, http://www.bea.gov/bea/dn1.htm, 1993-2003. 
Brooks, J., A. Cameron, and C. Carter (1998). Political Action Committee Contributions and U.S. Congressional Voting on Sugar Legislation. American Journal of Agriculatural Economics, 80(3), 441-454.

Cameron, C. and P. Trevidi (2005). Microeconometrics. Cambridge University Press.

Chib, S. (2007). Analysis of treatment response data without the joint distribution of potential outcomes. Journal of Econometrics. 140(2), 401-412.

Dahl, G (2002). Mobility and the Returns to Education: Testing a Roy Model with Multiple Markets. Econometrica, 70, 2367-2420.

Documentation for the 2004-05 Teacher Follow-up Survey, NCES product code 2007349 (only available online), http://nces.ed.gov/pubsearch/pubsinfo.asp?pubid=2007349, 2007.

Dubin, J. and D. McFadden (1984). An Econometric Analysis of Residential Electric Appliance Holdings and Consumption. Econometrica 52, 345-362.

Flyer, F. \& S. Rosen (1997) The New Economics of Teachers and Education. Journal of Labor Economics, 15(1), 104-39.

Garen, J. (1988). Compensating Wage Differentials and the Endogeneity of Job Riskiness. Review of Economics and Statistics, 70(1), 9-16.

Gilpin, G. and M. Kaganovich (2009). The Quantity and Quality of Teachers: A Dynamic Tradeoff. CESifo Working Paper 2516.

Goldhaber, D., \& Brewer, D. (2000). Does teacher certification matter? High school teacher certification status and student achievement. Educational Evaluation and Policy Analysis, 22(2), 129-145. 
Goldhaber, D. and A. Liu, 2003. "Occupational Choices and the Academic Proficiency of the Teacher Workforce," In: W. Fowler (ed.), Developments in School Finance 2001-02. NCES, Washington, DC, pp. 53-75.

Greenwald, R., Hedges, L., \& Laine, R. (1996, Fall). The effect of school resources on student achievement. Review of Educational Research, 66(3), 361-396. (EJ 596 389)

Hanushek, E., J. Kain, and S. Rivkin. (1999). Do higher salaries buy better teachers? Working Paper No. 7082. Cambridge: National Bureau of Economic Research.

--------------- (2004). Why Public Schools Lose Teachers. Journal of Human Resources, 39(2), 326-354.

Hanushek, E. J. Kain, D. O'Brien, and S. Rivkin (2005). The Market for Teacher Quality. NBER Working Papers 11154.

Hanushek, E, and S. Rivkin (1997). Understanding the Twentieth Century Growth in U.S. School Spending. Journal of Human Resources, 32(1), 35-68.

Hanushek, E. and S. Rivkin (2003). Does Public School Competition Affect Teacher Quality? NBER Chapters, in: The Economics of School Choice, pages 23-48.

Heckman, J. (1979). Sample selection bias as a specification error. Econometrica 47, 153-161.

Imazeki, J. (2005). Teacher salaries and teacher attrition. Economics of Education Review, 24(4), 431-449.

Lakdawalla, D., 2006. "The Economics of Teacher Quality," Journal of Law and Economics 49, 285-329.

Lancaster, T., 1990. The econometric analysis of transition data, Cambridge University Press, Cambridge. 
Lee, L., 1978. Unionism and Wage Rates: A Simultaneous Equations Model with Qualitative and Limited Dependent Variables. International Economic Review. 19(2), 415-33.

(1983). Generalized Econometric Models with Selectivity. Econometrica, 51, $507-512$.

Lee, L, and R. Trost, (1978). Estimation of some limited dependent variable models with application to housing demand. Journal of Econometrics 8, 357-382.

Loeb, S. and M. Page (2000). Examining the Link between Teacher Wages and Student Outcomes: The Importance of Alternative Labor Market Opportunities and Non-Pecuniary Variation. Review of Economics and Statistics, 82(3), 393-408.

Murnane, R and R. Olsen (1989). The Effect of Salaries and Opportunity Costs on Duration in Teaching: Evidence from Michigan. The Review of Economics and Statistics, 71(2), 347352.

Murnane, R., Willett, J., \& Levy, F. (1995, May). The growing importance of cognitive skills in wage determination. The Review of Economics and Statistics, 77(2), 251-66.

Ondrich, J., E. Pas, and J. Yinger (2008). The Determinants of Teacher Attrition in Upstate New York. Public Finance Review, 36(1), 112-144.

Scafidi, B., D. Sjoquist and T. Stinebrickner (2006). Do Teachers Really Leave for Higher Paying Jobs in Alternative Occupations?. Advances in Economic Analysis \& Policy, 6(1), 1604-1604.

Stinebrickner, Todd (2002). "An Analysis of Occupational Change and Departure from the Labor Force: Evidence of the Reasons that Teachers Leave.” Journal of Human Resources, $192-216$. 
Stoddard, Christiana, 2003. "Why Has the Number of Teachers per Student Risen While Teacher Quality Has Declined? The Role of Changes in the Labor Market for Women,” Journal of Urban Economics 53, 458-481.

The National Center for Education Statistics: Schools and Staffing Survey: Restricted-access data, 2003-04 and 1999-01.

The National Center for Education Statistics: Teacher Follow-up Survey: Restricted-access data, 2004-05 and 2000-01.

Noell, G. H. \& Burns, J. L. (2006). Value added assessment of teacher preparation: An illustration of emerging technology. Journal of Teacher Education. Education, Vol. 57, No. 1, $37-50$.

U.S. Bureau of the Census (3): Summary File 3, http://factfinder.census.gov/servlet/DownloadDatasetServlet?_lang=en, 2000.

University of California, San Diego: ACT to SAT converter, http://www.ucsd.edu/catalog/front/ACTtoSAT.html, 2006.

Wilson, S., Floden, R., \& Ferrini-Mundy, J. (2001). Teacher preparation research: Current knowledge, gaps, and recommendations. A research report prepared for the U.S. Department of Education. University of Washington, Center for the Study of Teaching and Policy, Seattle.

Wilson, S., Floden, R., \& Ferrini-Mundy, J. (2002). Teacher preparation research: An insider's view from the outside. Journal of Teacher Education, 53, 190-204. 
Table 1

Variables definitions and summary statistics

\begin{tabular}{|c|c|c|c|}
\hline Variable & Definition & Mean & S.D \\
\hline \multicolumn{4}{|l|}{ Teacher Characteristics } \\
\hline female & Female: 1 & 0.73 & 0.44 \\
\hline non-white & Non-white: 1 & 0.19 & 0.39 \\
\hline married & Married: 1 & 0.47 & 0.50 \\
\hline under age 27 & Under the age of $27: 1$ & 0.55 & 0.50 \\
\hline number of children under age 5 & Number of children under 5 & 0.26 & 0.54 \\
\hline ACT score & Imputed ACT score & 21.70 & 2.51 \\
\hline experience & Teacher's age - 24 & 7.77 & 7.25 \\
\hline squared experience & $(\text { Teacher's age- } 24)^{\wedge} 2$ & 112.84 & 186.01 \\
\hline ed. degree & Holds education degree: 1 & 0.51 & 0.50 \\
\hline special ed. degree & Holds special education degree: 1 & 0.09 & 0.28 \\
\hline math or science degree & Holds a math or science degree: 1 & 0.20 & 0.40 \\
\hline advanced degree & Holds an advanced degree: 1 & 0.16 & 0.36 \\
\hline advanced degreeXpublic & ADV_DEG*PUBLIC & 0.09 & 0.28 \\
\hline $\log$ (school wages) & Pervious year's wages as a teacher (in logs) & 10.32 & 0.24 \\
\hline outside teaching job & If person had outside teaching job during school year: 1 & 0.08 & 0.26 \\
\hline outside non-teaching job & If person had outside non-teaching job during school year: 1 & 0.15 & 0.36 \\
\hline household with over $\$ 40 \mathrm{~K}$ & If person lives in a household with income above $\$ 40 \mathrm{~K}$ (excluding their own) & 0.24 & 0.43 \\
\hline state certification & Teacher holds regular, standard state, or advanced professional certificate & 0.43 & 0.49 \\
\hline practicum & If teacher had a practicum: 1 & 0.81 & 0.39 \\
\hline \multicolumn{4}{|l|}{ Classroom Characteristics } \\
\hline class size & Teacher's average class size & 14.62 & 4.79 \\
\hline number of courses & Number of separate courses taught in given week & 3.15 & 3.87 \\
\hline attacked or threatened & Attached or threatened during school year & 0.12 & 0.32 \\
\hline \multicolumn{4}{|l|}{ School Characteristics } \\
\hline public & Public school: 1 & 0.61 & 0.49 \\
\hline union & School has union: 1 & 0.43 & 0.50 \\
\hline percent eligible for free lunch & Percent of students eligible for free lunch & 35.52 & 31.36 \\
\hline percent non-white & Percent of non-white students & 36.89 & 33.87 \\
\hline non-white teacher-students & Interaction between non-white teacher and percent non-white students & 11.61 & 28.21 \\
\hline lep & Percent of limited-English proficiency students & 5.41 & 14.31 \\
\hline iep & Percent of individual education plan students & 11.58 & 15.30 \\
\hline \multicolumn{4}{|l|}{ Community Characteristics } \\
\hline percent with $\mathrm{BA}+$ & Percent of area with at least a bachelor's degree (3-digit zip code level) & 22.57 & 10.67 \\
\hline community $\log$ (earnings) & log average earnings for community (3-digit zip code level) & 10.12 & 0.29 \\
\hline urban & Urban: 1 & 0.78 & 0.41 \\
\hline unemployment rate & Unemployment rate in percent (3-digit zip code level) & 6.21 & 2.81 \\
\hline year 2000 & Year 2000: 1 & 0.51 & 0.50 \\
\hline
\end{tabular}


Table 2

Mobility Rates of Teachers With 1 Year Teaching Experience

\begin{tabular}{lc}
\hline Teaching at the Same School & 74.6 \\
Teaching at a Different School & 14.8 \\
No Longer Teaching & 10.7 \\
Total & 100.0 \\
\hline
\end{tabular}

In percent.

Table 3

Occupational Status of Former Teachers With 1 Year Teaching Experience

\begin{tabular}{lcc}
\hline & & $\begin{array}{c}\text { Expected Occupation } \\
\text { Next School Year }\end{array}$ \\
\hline Full-time Teaching & Current Occupation & 27.7 \\
Non-Teaching Occupations Inside of Education & 0 & 15.0 \\
Occupations Outside of Education & 29.9 & 39.9 \\
Not in the Labor Force & 33.6 & 17.2 \\
Caring for Family Member & 21.4 & 7.3 \\
Student & 4.9 & 9.9 \\
Unemployed and Seeking Work & 16.5 & 0.1 \\
Total & 15.1 & 100.0 \\
\hline
\end{tabular}

In percent.

Table 4

Average Wages of Teachers With 1 Year Teaching Experience

\begin{tabular}{lccc}
\hline & $\begin{array}{c}\text { Former } \\
\text { Teachers }\end{array}$ & $\begin{array}{c}\text { Current } \\
\text { Teachers }\end{array}$ & $\begin{array}{c}\text { Difference in Wages } \\
\text { Across Groups }\end{array}$ \\
\hline Previous Year's Wages (1st year as a Teacher) & 30,106 & 33,522 & 3,416 \\
Current Year's Wages (2nd year) & $34,385^{\mathrm{a}}$ & 34,789 & 404 \\
Difference In Wages Across Years & 4,280 & 1,267 & \\
\hline
\end{tabular}

All wages are in 2004 dollars.

a: Includes only individuals who are currently employed full-time. 
Table 5

Estimates for Salary Equations

\begin{tabular}{|c|c|c|}
\hline & $\ln ($ Teacher Wage $)$ & $\ln$ (Outside Wage) \\
\hline \multicolumn{3}{|l|}{ Teacher Characteristics } \\
\hline constant & $1.638(.536) * * *$ & $1.866(2.922)$ \\
\hline $\log$ (school wages) & $.824(.052) * * *$ & $.577(.189) * * *$ \\
\hline female & $-.054(.023) * *$ & $-.032(.088)$ \\
\hline non-white & $.035(.025)$ & $.151(.093)$ \\
\hline married & $-.024(.021)$ & $-.071(.087)$ \\
\hline household with over $\$ 40 \mathrm{~K}$ & $-.005(.025)$ & $-.604(.193) * * *$ \\
\hline ACT score & $.005(.004)$ & $-.009(.016)$ \\
\hline education degree & $.038(.022) *$ & $.071(.098)$ \\
\hline math or science degree & $-.012(.025)$ & $.022(.093)$ \\
\hline advanced degree & $.047(.048)$ & $.089(.100)$ \\
\hline advanced degreeXpublic & $-.035(.059)$ & --- \\
\hline special ed. degree & $-.073(.039) *$ & --- \\
\hline state certification & $-.057(.023) * * *$ & \\
\hline experience & --- & $-.015(.022)$ \\
\hline squared experience & -- & $.001(.000)$ \\
\hline \multicolumn{3}{|l|}{ School Characteristics } \\
\hline public & $.033(.029)$ & --- \\
\hline union & $.043(.025) *$ & --- \\
\hline \multicolumn{3}{|l|}{ Community Characteristics } \\
\hline urban & $-.005(.028)$ & $.012(.101)$ \\
\hline community log(earnings) & --- & $.381(.253)$ \\
\hline percent with $\mathrm{BA}+$ & --- & $-.011(.007) *$ \\
\hline year 2000 & --- & $.004(.084)$ \\
\hline Log likelihood & -179.10 & -376.96 \\
\hline$\rho$ & $.857(.046) * * *$ & $-.841(.134) * *$ \\
\hline$\lambda$ & $.142(.018) * * *$ & $-.475(.146) * *$ \\
\hline
\end{tabular}

Note: $A *$ signifies statistical significance at the 10 percent level, $* *$ signifies statistical significance at the 5 percent level, and $* * *$ signifies statistical significance at the 1 percent level. 
Table 6

Structural Equation Estimates - Marginal Effects

\begin{tabular}{|c|c|}
\hline & Exit Decision \\
\hline \multicolumn{2}{|l|}{ Teacher Characteristics } \\
\hline non-teaching wage & $-.020(.063)$ \\
\hline teaching wage & $-.277(.074) * * *$ \\
\hline outside teaching job & $-.007(.048)$ \\
\hline outside non-teaching job & $.078(.041) * *$ \\
\hline practicum & $-.120(.042) * * *$ \\
\hline state certification & $-.057(.029) * *$ \\
\hline household with over $\$ 40 \mathrm{~K}$ & $.400(.037) * * *$ \\
\hline female & $.014(.031)$ \\
\hline non-white & $.018(.036)$ \\
\hline under age 27 & $-.030(.028)$ \\
\hline married & $.002(.028)$ \\
\hline number of children under age 5 & $.043(.023) *$ \\
\hline ACT score & $.008(.005)$ \\
\hline education degree & $.0052(.030) *$ \\
\hline math or science degree & $.001(.032)$ \\
\hline advanced degree & $.005(.038)$ \\
\hline special ed. degree & $-.062(.041)$ \\
\hline \multicolumn{2}{|l|}{ Classroom Characteristics } \\
\hline \multicolumn{2}{|l|}{ School Characteristics } \\
\hline public & $.012(.034)$ \\
\hline union & $-.104(.033) * * *$ \\
\hline \multicolumn{2}{|l|}{ Community Characteristics } \\
\hline percent with $\mathrm{BA}+$ & $.002(.002)$ \\
\hline community $\log$ (earnings) & $-.206(.101) *$ \\
\hline urban & $-.026(.036)$ \\
\hline unemployment rate & $-.015(.005) * * *$ \\
\hline year 2000 & $.356(.085) * * *$ \\
\hline Log likelihood & -476.7 \\
\hline Pseudo $\mathrm{R}^{2}$ & .2169 \\
\hline
\end{tabular}

Note: A* signifies statistical significance at the 10 percent level, ** signifies statistical significance at the 5 percent level, and $* * *$ signifies statistical significance at the 1 percent level. 
Table 7

Structural Equation Estimates for Exit Decision by Gender Marginal Effects

\begin{tabular}{lll}
\hline & Female & Male $^{\mathrm{a}}$ \\
& & \\
\hline $\begin{array}{l}\text { Teacher Characteristics } \\
\text { non-teaching wage }\end{array}$ & $.002(.081)$ & $-.011(.121)$ \\
teaching wage & $-.280(.076)^{* * *}$ & $-.721(.269)^{* * *}$ \\
$\quad$ outside teaching job & $.024(.060)$ & $-.113(.065)$ \\
outside non-teaching job & $.054(.050)$ & $.089(.069)$ \\
practicum & $-.074(.046)^{*}$ & $-.224(.085)^{* * *}$ \\
$\quad$ state certification & $-.052(.033)$ & $-.121(.056)^{* *}$ \\
household with over $\$ 40 \mathrm{~K}$ & $-.360(.043)^{* * *}$ & $-.567(.078)^{* * *}$ \\
Classroom Characteristics & & $.279(.103)^{* * *}$ \\
attacked or threatened & $.076(.054)^{*}$ & \\
School Characteristics & & $-.120(.069)^{*}$ \\
$\quad$ union & $-.086(0.035)^{* *}$ & \\
Community Characteristics & & $-.158(.210)$ \\
$\quad$ community log(earnings) & $-.228(.114)^{* *}$ & $-.021(.010)^{* *}$ \\
unemployment rate & $-.014(.007)^{* *}$ & -119.9 \\
\hline Log likelihood & -344.10 & .3160 \\
Pseudo R-squared & .2036 & 301 \\
Observations & 817 &
\end{tabular}

a: MLE did not coverge. Estimated through Heckman's two-step method.

Note: All other regressors included as specified in Section 3.

A * signifies statistical significance at the 10 percent level, ** signifies statistical significance at the 5 percent level, and $* * *$ signifies statistical significance at the 1 percent level. 
Table 8

Structural Equation Estimates - Marginal Effects

Exit Decision

Baseline Specification Extended Specification ${ }^{\mathrm{a}}$ Reduced Specification

\begin{tabular}{|c|c|c|c|}
\hline \multicolumn{4}{|l|}{ Teacher Characteristics } \\
\hline non-teaching wage & $-.020(.063)$ & $-.014(.069)$ & $.024(.054)$ \\
\hline teaching wage & $-.277(.074) * * *$ & $-.287(.078) * * *$ & $-.350(.080) * * *$ \\
\hline outside teaching job & $-.007(.048)$ & $-.025(.056)$ & $-.016(.047)$ \\
\hline outside non-teaching job & $.078(.041) * *$ & $.072(.043) *$ & $.075(.040) * *$ \\
\hline practicum & $-.120(.042) * * *$ & $-.124(.046) * * *$ & $-.150(.040) * * *$ \\
\hline state certification & $-.057(.029) * *$ & $-.042(.031)$ & $-.056(.028) * *$ \\
\hline household with over $\$ 40 \mathrm{~K}$ & $.400(.037) * * *$ & $.382(.041) * * *$ & $.416(.037) * * *$ \\
\hline female & $.014(.031)$ & $.002(.003)$ & -- \\
\hline non-white & $.018(.036)$ & $-.067(.059)$ & --- \\
\hline under age 27 & $-.030(.028)$ & $-.052(.031) *$ & --- \\
\hline married & $.002(.028)$ & $-.004(.031)$ & --- \\
\hline number of children under age 5 & $.043(.023) *$ & $.019(.024)$ & $.039(.022) *$ \\
\hline ACT score & $.008(.005)$ & $.008(.006) *$ & $.010(.005) * *$ \\
\hline education degree & $.0052(.030) *$ & $-.049(.035)$ & \\
\hline math or science degree & $.001(.032)$ & $.001(.035)$ & --- \\
\hline advanced degree & $.005(.038)$ & $.007(.042)$ & --- \\
\hline special ed. degree & $-.062(.041)$ & $-.052(.045)$ & --- \\
\hline \multicolumn{4}{|l|}{ Classroom Characteristics } \\
\hline attacked or threatened & $.131(.053) * * *$ & $.101(.049) * *$ & $.118(.049) * * *$ \\
\hline number of courses & -- & $.001(.004)$ & -- \\
\hline class size & --- & $.001(.003)$ & --- \\
\hline \multicolumn{4}{|l|}{ School Characteristics } \\
\hline public & $.012(.034)$ & $.019(.037)$ & \\
\hline union & $-.104(.033) * * *$ & $-.095(.032) * * *$ & $-.084(.029) * * *$ \\
\hline percent eligible for free lunch & -- & $-.001(.001)$ & -- \\
\hline percent non-white & --- & $-.001(.001)$ & --- \\
\hline non-white teacher-students & --- & $.001(.001)$ & --- \\
\hline lep & --- & $-.001(.001)$ & --- \\
\hline iep & --- & $-.001(.001)$ & --- \\
\hline \multicolumn{4}{|l|}{ Community Characteristics } \\
\hline percent with $\mathrm{BA}+$ & $.002(.002)$ & $.002(.003)$ & --- \\
\hline community $\log$ (earnings) & $-.206(.101) *$ & $-.214(.112)$ & $-.127(.051) * * *$ \\
\hline urban & $-.026(.036)$ & $-.017(.039)$ & --- \\
\hline unemployment rate & $-.015(.005) * * *$ & $-.014(.006) * *$ & $-.012(.005) * *$ \\
\hline year 2000 & $.356(.085) * * *$ & $.061(.031) * *$ & $.483(.095) * * *$ \\
\hline Log likelihood & -478.43 & -389.22 & -480.76 \\
\hline Pseudo $\mathrm{R}^{2}$ & .2140 & 0.2271 & 0.2102 \\
\hline Observation & 1118 & 947 & 1118 \\
\hline
\end{tabular}

a: MLE did not converge. Estimated through Heckman's two-step method.

Note: A * signifies statistical significance at the 10 percent level, $* *$ signifies statistical significance at the 5 percent level, and *** signifies statistical significance at the 1 percent level. 